\title{
PENYIMPANGAN DALAM \\ TAFSIR AL-QUR'AN
}

\section{Salman Parisi}

Sekolah Tinggi Agama Islam Madinatul Ilmi

salman.parisi15@gmail.com

\section{Abstract}

Al-Qur'an is the revelation of Allah Almighty which was revealed as the guidance for human being until the end of time. Therefore, the Qur'anic text does not change, but its interpretation can be influenced by various factors that sometimes cause distortion. Distortion occurs when interpretation is no longer conducted suitable with predetermined lines, which are methodology of AlQur'an interpretation that has been agreed as the first step for every interpreter either in language acquisition, understanding the history of descending Al-Qur'an, supporting sciences related to it and the 'super strict' conditions that must be possessed by every interpreter. This article discusses about the factors of misinterpretation which include following al-Mutashabihat and ignoring al-Muhkamat, bad judgment, placing the sentence (nas) not in the proper position, Nasakh claims as the sign of theorem, nescience towards Sunnah and Athar, more trusting in Isra'iliyyat, turn away from the ummah agreement and weak in science.

Keywords: factors, Distortion, Interpretation 


\section{Abstrak}

Al-Qur'an merupakan wahyu Allah Swt yang diturunkan sebagai petunjuk bagi manusia sampai akhir zaman. Karena itu, teks Al-Qur'an tidak mengalami perubahan, namun penafsiran terhadapnya bisa dipengaruhioleh berbagai faktoryang terkadang menyebabkan penyimpangan. Penyimpangan terjadi ketika penafsiran tidak lagi dilakukan sesuai dengan garis-garis yang sudah ditetapkan yaitu metodologi penafsiran al-Qur'an yang sudah disepakati sebagai langkah awal bagi setiap penafsir baik dalam penguasaan bahasa, memahami sejarah diturunkannya al-Qur'an, ilmu-ilmu penopang yang berkaitan dengannya serta syarat-syarat 'super ketat' yang harus dimiliki oleh setiap penafsir. Artikel ini membahas seputar faktor-faktor penyimpangan tafsir yang di antaranya mengikuti al-Mutāshābihat dan mengabaikan al-Muhkamāt, penakwilan yang buruk, meletakkan kalimat (nas) bukan tidak pada posisi seharusnya, klaim Nasakh tanda dalil, ketidaktahuan terhadap Sunnah dan Āthār, lebih percaya pada Isrä'iliyyāt, keberpalingan dari kesepakatan umat dan lemah dalam ilmu pengetahuan.

Kata kunci: faktor-faktor, penyimpangan, tafsir 


\section{A. PENDAHULUAN}

l-Qur'an adalah kitab Allah yang terakhir diturunkan untuk
dijadikan pedoman bagi umat manusia hingga akhir dunia
ini. Kaum Muslim menyakini bahwa al-Qur'an adalah wahyu Tuhan yang sudah tidak lagi diragukan kebenarannya, dan para ulama memandang bahwa al-Qur'an memiliki kebenaran yang absolut. ${ }^{1} \mathrm{Al}$-Qur'an adalah kitab suci bagi umat Islam yang memberi petunjuk kepada jalan yang benar. Di samping itu, ia berfungsi untuk memberikan jalan kesejahteraan dan kebahagiaan bagi manusia, baik secara pribadi maupun masyarakat. ${ }^{2}$

Al-Qur'an jalan yang lurus; cahaya dan rahmat bagi orang-orang beriman; kitab yang menjunjung tinggi akal dan pemikiran; kitab yang penuh dengan hikmah dan informasi pengetahuan; kitab yang mengajak manusia untuk berbuat dan beramal baik; kitab yang memuat berbagai penjelasan; kabar gembira dan ancaman; kitab tentang keadilan, kebaikan dan petunjuk ketakwaan...ia merupakan kitab yang membawa ketenangan dan kedamaian ke dalam jiwa; kitab yang penuh dengan 'ibrah dan peringatan; kitab yang mengajak pada kejayaan dalam kehidupan baik di dunia mau pun di akhirat.

Di samping itu, menurut al-Șamālī dalam tulisannya bahwa al-Qur'an memang dikondisikan sebagai kitab penjelas bagi apa-apa yang dibutuhkan manusia, yang tujuannya adalah agar manusia hidup tentram dan bahagia. ${ }^{3} \mathrm{Hal}$ ini karena menurut alȚabāțabāîi, al-Qur'an berisi serangkaian ajaran yang diturunkan kepada Rasulullah saw untuk menunjukan kepada umat manusia jalan menuju kebahagiaan. Al-Qur'an terdiri dari serangkaian tema teoritis dan praktis untuk umat manusia. Apabila semua ajaran tersebut dilaksanakan, kita akan memperoleh kebahagiaan di

1 J.M.S. Baljon, Tafsir Qur'an Muslim Modern, pent A. Ni'amullah Mu'iz, (Jakarta: Pustaka Firdaus, 1991), h.1

2 M. Quraish Shihab, Membumikan al-Qur'an: Fungsi dan Peran Wahyu Dalam Kehidupan Masyarakat, (Bandung: Mizan, 1994), h. 172

3 Muḥammad 'Alī Șāmālī, Understanding God's Mercy Part IV, Quarterly Journal of Islamic Studies, Message of Thaqalayn. Vol 12, No 4 (London: Islamic Centre of England, Winter 1433/2012), h. 12. 
dunia dan akhirat. ${ }^{4}$

Al-Qur'an secara teks memang tidak mengalami perubahan, ia tidak lekang oleh waktu, tetapi proses penafsiran atasnya, selalu berubah sesuai dengan konteks ruang dan waktu manusia. AlQur'an bukan kitab yang tertutup; Ia adalah kitab terbuka yang selalu membuka diri untuk dianalisis, dipersepsi dan diinterpretasi dengan berbagai alat, metode dan pendekatan untuk menguak isi sejatinya. Dalam sejarahnya, telah diajukan beberapa metode tafsir sebagai jalan untuk membedah makna terdalam dari al-Qur'an. ${ }^{5}$

Secara historis, Rasulullah saw merupakan interpretator dari al-Qur'an. Dia senantiasa memberikan pengarahan apa yang ada di dalam kitab al-Qur'an baik yang bersifat Mujmal dan ringkas, yang sifatnya 'Ām atau yang dikhususkannya. Menerangkan kandungan al-Qur'an baik yang tersurat maupun tersirat, menjelaskan, memaparkan kalam Ilahi pada sahabat-sahabatnya dalam perintah maupun larangan-Nya. Hal ini ditunjukkan dengan adanya beberapa sahabat yang bertanya kepada Nabi tentang beberapa lafadz dan makna dalam ayat al-Qur'an yang tidak di mengerti. Hal ini wajar saja, mengingat Nabi adalah sosok sentral yang dijadikan rujukan oleh umat. ${ }^{6}$ Dengan ungkapan lain, beliau adalah seorang Nabi sekaligus mufassir utama al-Qur'an. Kedudukan ini dijelaskan di dalam firman Allah swt:

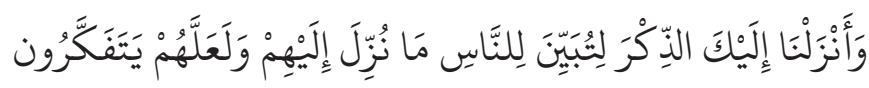

"Dan Kami turunkan kepadamu al-Qur'an, agar kamu menerangkan kepada umat manusia apa yang telah diturunkan kepada mereka dan supaya mereka memikirkan. (QS: al-Nahl [16]: 44).

Semua itu bertujuan agar manusia tidak tersesat dan melenceng dari jalan yang telah dicanangkan Allah swt, dalam rangka untuk membentuk karakter insani agar berjalan menuju keridaan-Nya

4 Muhammad Ḥusayn al-Țabāțabā'ī, Inilah Islam, Pemahaman Dasar Konsep-konsep Islam, cetakan pertama (Jakarta: Sadra press, 2011), h. 119.

5 Umar Shihab, Kontekstualitas Al-Qur'an, kajian tematik atas ayat-ayat hukum dalam al-Qur'an, (Jakarta: Penamadani, 2003), h. 3

6 Muhammad Husain al-Dzahabi, al-Tafsìr wa al-Mufassirūn, (Dār al-Hadīs, Kairo, 2005), h. 46-7.

HIKMAH, Vol. XV, No. 2, 2019 299 
dalam kehidupan sehari-hari.

Pada awalnya, saat Rasulullah saw berada di antara mereka, maka segala masalah yang terjadi akan terselesaikan secara otomatis. Saat itu, apapun masalah yang diajukan, jalan keluar bagi kesulitan yang dihadapi, solusi bagi ketetapan penyelesaian konflik serta kegundahan saat menghadapi problema, semuanya akan terjawab melalui wahyu Allah swt yang diturunkan kepadanya. Hal ini dijelaskan dalam firman Allah swt,

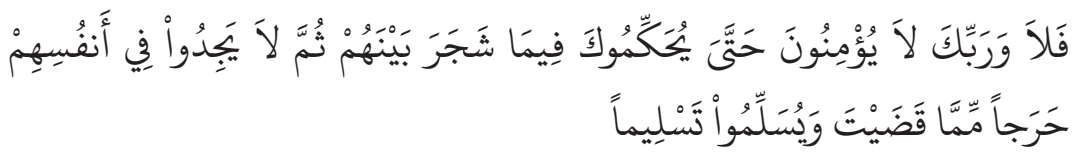

"Maka demi Tuhanmu, mereka (pada hakekatnya) tidak beriman hingga mereka menjadikan kamu hakim dalam perkara yang mereka perselisihkan, kemudian mereka tidak merasa keberatan dalam hati mereka terhadap putusan yang kamu berikan, dan mereka menerima dengan sepenuhnya" \{(QS. al-Nisā’ [4]: 65\}).

Bahkan Allah swt dalam firman-Nya telah mengecam mereka yang hanya sekedar mencoba dalam melakukan pilihan lain, takala Allah dan rasul-Nya telah mengukuhkan satu ketetapan, "Dan tidaklah patut bagi laki-laki yang mukmin dan tidak (pula) bagi perempuan yang mukmin, apabila Allah dan Rasul-Nya telah menetapkan suatu ketetapan, akan ada bagi mereka pilihan (yang lain) tentang urusan mereka. Dan barangsiapa mendurhakai Allah dan Rasul-Nya maka sungguhlah dia telah sesat, sesat yang nyata" $\{\mathrm{QS}$. AlAḥzāb (33) :36\}.

Saat Rasulullah saw berada di sisi mereka, semua penafsiran alQur'an akan dikembalikan pada Nabi saw, setelah itu Beliau ajarkan dan paparkan pada mereka. Hal demikian itu adalah pemandangan yang biasa dan senantiasa disaksikan oleh para sahabat, dan alQur'an telah memerintahkan ini dalam firman-Nya;

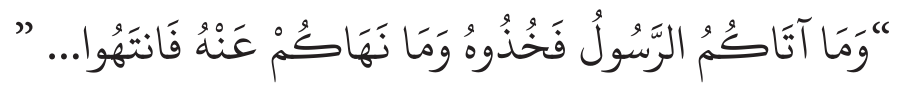

“...Apa yang diberikan Rasul kepadamu maka terimalah dia. Dan apa yang dilarangnya bagimu maka tinggalkanlah...” 
Namun, pasca wafatnya Rasulullah saw, timbul permasalahan pada penafsiran al-Qur'an. Hal ini karena dengan wafatnya Beliau saw menjadikan para sahabat kehilangan interpretator yang dapat menjelaskan segala masalah yang rancu, memaparkan seluruh hal yang tersirat serta mengurai berbagai benang kusut dalam setiap kasus. Setelah kepergian Beliau, maka timbul penafsiran generasi awal yang terus bergolak dan berkembang pada generasi sesudahnya dan begitu pula selanjutnya hingga pada masa sekarang ini.

Tak dapat dipungkiri bahwa di sana terdapat para sahabat yang konsist menjelaskan dan menafsirkan al-Qur'an merujuk pada petuah dan sabda yang mereka peroleh dari Nabi saw karena kesatuan masa mereka dengan Beliau serta ingatan yang masih segar pada apa yang diajarkan Beliau. Penafsiran yang semacam ini akan dapat dan bahkan wajib diterima pada kondisi tertentu, bagaimana tidak, Rasulullah saw adalah manusia yang terhindar dari kesalahan dalam misi risalahnya, hingga hal-hal yang diajarkan dan langsung diterima oleh para sahabatnya pastilah sesuatu yang terhindar dari kesalahan. Jika tidak, maka sifat al-'Işmah ${ }^{7}$ yang dimiliki Rasulullah tidaklah mempunyai nilai apa-apa.

Pasca kepergian Rasulullah saw timbullah berbagai cara yang ditempuh para sahabat dalam menafisrkan al-Qur'an, sebagaimana cara ini ditempuh pula oleh generasi yang datang setelah mereka. Adanya kesenjangan politik pada masa sahabat serta terpilahpilahnya kehidupan bermasyarakat menjadikan berkubu-kubu, di samping banyaknya para sahabat yang memahami penafsiran alQur'an gugur sebagai syuhada di medan jihad, membuat sebagian penafsiran al-Qur'an dapat dipastikan telah terkontaminasi dengan berbagai aliran yang di antaranya adalah ideologi dan fanatisme.

Di tambah lagi dengan raibnya sunnah-sunnah Nabi yang

7 Kata Işmah dalam bahasa berarti protek atau menahan diri. Lihat; Khalil al-Jurr, Al-Mu'jam al-Arabi al-Hadìth Larousse (Paris: Maktabah La Rose, 1973), h.194. Demikian pula apa yang ditulis ole Kamāl al-Ḥaydarī mengenai al-'Işmah. Lihat; Sayyid Kamāl al-Haydarī, al-'Işmah, Baḥth Taḥlīlī Fī D \{au'i al-Manhaj al-Qur'ānī, cetakan pertama (Bayrūt: Dār al-Kutub al-'Arabī, 2002), h. 83. Masalah ini disinggung pula oleh al-Sāmāli.> Lihat; http://www.ic-el.com/en/admin/uploadfolder/articles/48wilayah\%20part\%20iii.pdf h. 152 (20/09/2018). Ibn Ḥajar ketika memaparkan keutamaan sahabat berkata, "Al-Işmah itu hukumnya wajib pada para Nabi, sedangkan pada selain mereka, hal itu bisa saja terjadi”. Lihat; Aḥmad ibn Ḥajar al-'Asqalānī, Fatḥ al-Bārī Bi Sharaḥ Şaḥị̣̄ al-Bukhārī, juz 7 (AlQāhirah: Dār al-Ḥadìth, 2004), h. 53. 
dicatat oleh para sahabat dalam catatan mushaf-mushaf mereka serta larangan penulisan hadis dan kodivikasi pada masa sahabat hingga masa tabiin sebagaimana dituturkan oleh 'Ajjāj dalam bukunya, ${ }^{8}$ yang salah satu fungsi hadis (dibaca al-Sunnah) sebagai interpretator al-Qur'an, penjelas dan perinci ayat-ayatnya yang bersifat global membuat peluang emas bagi para spekulan dalam melakukan penafsiran sesuai kepentingan masing-masing. Dengan itu, betapa banyak penyimpangan-penyimpangan yang terjadi hingga kita rasakan hingga saat ini.

\section{B. DEFINISI PENYIMPANGAN TAFSIR.}

Penyimpangan dalam judul di atas adalah terjemahan dari bahasa Arab yang asalnya adalah al-Inhirāf (الانخراف) bentuk jama'nya adalah al-Inhiräfāt (الانحرافات). Jika kembali pada kamus bahasa Arab, maka kata al-Inhirāf mempunyai banyak makna yang di antaranya adalah, "Berpaling, pola berpikir menyimpang, keluar dari jalur yang lurus dan menjauh darinya. Sementara dalam ilmu sosial dapat diartikan keluar dari sesuatu yang telah menjadi tradisi dan umum, dan dari sudut geografis berarti melenceng dari Katulistiwa..." ${ }^{9}$ Dengan demikian dapat ditarik kesimpulan bahwa kata al-Inhirāf adalah keberpalingan dari garis yang sudah ditetapkan.

Sementara kata al-Tafsir dalam kamus bahasa juga mempunyai banyak makna yang di antaranya adalah, "Penjelasan dan pemaparan, Tafsir al-Qur'an adalah penjelasan makna-maknanya dan pemaparan ketinggian serta keistimewaan bahasanya dan menguraikan sebab-seba turun ayat-ayatnya beserta kandungan hukum yang terdapat di dalamnya" ${ }^{10}$ Sementara menurut 'Abd al-

8 Berkata Muhammad 'Ajjāj setelah menyelidiki asal muasal larangan penulisan sunnah, "Aku dapatkan sebagaimana yang dikatakan oleh al-Khatīb al-Baghdādī, 'Tidak disukainya penulisan sunnah pada masa awal Islam sesungguhnya agar tidak menyerupai kitab Allah set dengan yang lainnya, atau disibukkan pada selain al-Quran.”' Lihat: Muhammad 'Ajjāj al-Khatīb, Ushūl al-Hadìth, Ulūmuh wa Mustalāhuh, cetakan dan terbitan baru (Bayrut: Dār al-Fikr li al-Tabā'ah wa al-Nashr wa al-Tawzì', 2006), h. 103. Hal ini pun diisyaratkan oleh Subhī Sālih, 'Ulūm al-Hadìth wa Mustalāhuh, cetakan ke tujuh belas. (Bayrut: Dār al-'Ilm Li al-Malāyīn, 1988), h. 40.

9 Lihat; Mu'jam 'Arabì 'Arabì. http://tinyurl.com/qetz6rh (24/09/2018).

10 Lihat; Mu'jam 'Arabi 'Arabì. http://tinyurl.com/pljctal (24/09/2108). 
Qādir Muhammad al-Ḥusayn, ${ }^{11}$ "Penjelasan sebagaimana dalam alQur'an, 'Wa Ahasana Tafsìrä' dapat pula diartikan sebagai membuka sesuatu yang tertutup ${ }^{12}$, paparan pada kalimat yang ambigu. Tafsīr al-Bawl adalah petunjuk bagi para dokter yang memeriksa pasien ketika meneliti penyakit yang diderita dari warna urinenya". ${ }^{13}$

Dariketerangandiatasmakadapatdisimpulkanbahwaungkapan dari Inhiriāāt fì al-Tafsīr al-Qur'an adalah faktor-faktor penyebab penyimpangan dalam tafsir al-Qur'an, atau keberpalingan para penafsir al-Qur'an dari jalur-jalur yang seharusnya dilalui mereka sebelum memasuki dan menjelajah ke dalam al-Qur'an. Ungkapan garis-garis yang sudah ditetapkan akan masuk di dalamnya yaitu metodologi penafsiran al-Qur'an yang sudah disepakati sebagai langkah awal bagi setiap penafsir baik dalam penguasaan bahasa, memahami sejarah diturunkannya al-Qur'an, ilmu-ilmu penopang yang berkaitan dengannya serta syarat-syarat 'super ketat' yang harus dimiliki oleh setiap penafsir. seputar sebab penyimpangan tafsir inilah yang akan dibahas penulis pada halaman mendatang.

Telah banyak kajian terhdap materi ini dan hampir setiap pengkaji menyajikan berbagi faktor tentang sebab musabab adanya penyimpangan dalam penafsiran al-Qur'an. Sebagai contoh adalah tulisan Yūsūf al-Qardawī dalam kitabnya Kayfa Nata'amal Ma'a al-Qur'ān al-Karìm yang telah menyebutkan pula faktorfaktor penyebab hal itu. Selain beliau ialah Muhammad Husayn al-Dhahabī dalam kitabnya al-Ittijāhāt al-Munharifah fi Tafsìr alQur'ān al-Aqwāl al-Shädhdhah fi al-Tafsìr Nash'atuha wa Asbabuha wa Athāruha serta yang lainnya.

11 'Abd al-Qādir Muhammad al-Ḥusayn lahir pada tahun 1971 M dan dia adalah anggota dan team pengajar di Universitas Damascus dan Profesor di bidang Tafsīr wa 'Ulūm al-Qur'ān pada Fakultas al-'Ulūm al-Islāmiyyah di Universitas Yālū. Sumber; http://tinyurl.com/qfewtps (24/09/2018).

12 Hal ini disinggung pula oleh al-Sibt dalam kitabnya. Lihat; Khalid ibn 'Uthmān al-Sibt, Qawāid al-Tafsīr Jam'an wa Dirāsatan, juz 1 (Tanpa Negara, Dār al-'Affān, Tanpa tahun), 25.

13 'Abd al-Qādir Muhammad al-Ḥusayn, Tamyīz al-Dakhīl fỉ Tafsīr al-Qur'ān al-Karīm, Fakultas al-Sharīah wa al-Qānūn, Jurnal Universitas Damascus, edisi 29 tahun 2013 (PDF). 


\section{FAKTOR-FAKTOR PENYIMPANGAN DALAM TAFSIR AL-QUR'AN}

Al-Dhahabī menulis dalam kitabnya, "Sebagaimana kita ketahui pada masa awal perjalanan tafsir di era periwayatan dan era kodivikasi, dan kita juga memahami bagaimana mereka telah 'memangkas' mata rantai transmisi pada tafsir Bi al-Ma'thūr lalu mereka menyebutkan tanpa menyertakan perawinya, juga penafsiran secara akal (Tafsìr al-'Aqlī) yang erat sekali dengan kepribadian penafsirnya serta aliran yang diyakininya."14

Dengan menghilangkannya mata rantai trasmisi pada hadishadis yang berhubungan dengan penafsiran al-Qur'an di mana 'Abd Qādir al-Husayn mengomentari hal ini, "Sudah berlumpur disiram air pula", ${ }^{15}$ maka hal ini pasti akan membuka pintu-pintu tipudaya serta kejahatan atas kaum muslimin dan peluang emas untuk menyisipkan hal-hal yang dimaukan oleh musuh-musuh Islam sangatlah besar sebagaimana ini terjadi pada tafsir-tafsir al-Dhakill, itu jika ditinjau dari sudut external. Namun kita juga tidak bisa menutup mata begitu saja dan mengabaikan sudut internal, atau hanya memandang dengan sebelah mata pada para penafsir yang memang mempunyai kepentingan idiologi dan keyakinan serta bercorak politik dan afiliasi madzhab. Karena merekapun berusaha dalam mencari justifikasi demi kepentingan madzhab dan aliran politiknya sebagaimana inipun disinggung pula oleh al-Dhahabī dalam kitabnya.

Secara internal Quraisy Shihab mengemukakan bahwa terdapat beberapa kekurangan beberapa pendekatan tafsir. Misalnya pada tafsir bi al-Mathūr terdapat dua kekurangan: pertama, sang mufassir terjebak dalam uraian kebahasaan dan kesustraan yang bertele-tele, sehingga pesan pokok al-Qur'an menjadi kabur. Kedua, seringkali konteks turunnya ayat (uraian asbāb an-nuzūl atau situasi

14 Muḥammad Ḥusayn al-Dhahabī. Ittijāhāt al-Munharifah fì Tafsīr al-Qur'ān al-Karīm wa Dawāfi'uha wa Daf'uha, cetakan ketiga (al-Qāhirah: Maktabah Wahbah, 1986), h. 18. Sumber: https:// ia801305.us.archive.org/25/items/emtqkddemtqkdd/emtqkdd.pdf (9/9/18).

ما زاد الطين بلة ز 15 ('Abd al-Qādir Muḥammad al-Husayn, Tamyīz al-Dakhīl fì Tafsīr al-Qur'ān alKarīm, Fakultas al-Sharīah wa al-Qānūn, Jurnal Universitas Damascus, edisi 29 tahun 2013 (PDF). h. 341. 
kronologis turunnya ayat-ayat hukum yang dipahami dari uraian nasīkh mansūkh) hampir dapat dikatakan terabaikan sama sekali, sehingga ayat tersebut bagaikan turun bukan dalam suatu masa tertentu atau berada di tengah-tengah masyarakat tanpa budaya. ${ }^{16}$ Sementara Said Husin al-Munawwar menyebutkan kelemahan dari tafsir bi al-Mathür di antaranya adalah terbatasnya persediaan riwayat yang merupakan tafsir ayat-ayat al-Qur'an, sehingga tidak terlalu banyak diharapkan bisa menjawab berbagai problem yang dihadapi masyarakat dari masa ke masa. Selain itu, hadis-hadis yang adapun masih memerlukan penelitian yang amat cermat karena masih banyak tercapur dengan Isrā'iliyāt. ${ }^{17}$ Banyak orang merasa berat menerima tafsir batiniah dari ayat-ayat al-Qur'an. Pertama, mereka kuatir, dengan hanya mengambil makna batiniah, tafsir sufi mengabaikan makna lahiriah. Akibatnya, syariat bisa dilecehkan atau ditinggalkan sama sekali. Karena menerima ta'wil (takwil), akhirnya orang meninggalkan tanzil. Kedua, pengambilan makna batiniah seringkali mengabaikan hokum-hukum bahasa Arab. Makna denotative dari berbagai makna ditundukkan pada makna makna konotatif, yang diperoleh seseorang dari pengalaman ruhaniah, pada gilirannya, sangat subjektif dan irasional (atau suprarasional), sehingga sulit diverifikasi. ${ }^{18}$

Sebagaimana pada kasus tafsir al-Dakhīl, bahwa adanya penyimpangan dalam tafsir Bi al-Ma'thür waktunya sezaman dengan adanya penyimpangan dalam riwayat hadis Nabawi, karena keduanya tidak dapat dipisahkan. Demikian pula tentang riwayat pada penafsiran al-Qur'an posisinya akan sejalan dengan periwayatan hadis baik dari kesahihan atau kelemahannya, kokoh atau cacat perawinya

Memang di sana terdapat banyak faktor tentang penyimpangan dalam penafsiran al-Qur'an yang ditulis dan dipaparkan oleh para ulama yang bergelut di bidang tafsir serta apa-apa yang

16 M. Quraisy Shihab, Membumikan al-Quran: Fungsi dan Peran Wahyu dalam Kehidupan Masyarakat, (Bandung: Mizan, 2012), h. 84.

17 Said Agil Husin al-Munawwar, Al-Quran Membangun Tradisi Kesalehan Hakiki, (Tangerang Selatan: Ciputat, 2005), h. 22.

18 Jalaluddin Rakhmat, Tafsir Sufi al-Fatihah, (Bandung: Mizan Media Utama, 2012), cetakan 1, h. 17. 
berkaitan dengannya. Dan setiap pengkaji membuahkan hasil yang melengkapi satu sama lain dengan komposisi senada namun dengan redaksi berbeda. Pada makalah ini pemakalah akan memaparkan pandangan Yūsūf al-Qardawī dalam kitabnya Kayfa Nata'āmal Ma'ā al-Qur'ān yang menyebutkan penyebab ketergelinciran para penafsir (baik bi al-Ma'tsūr, bi al-Ra'yī atau bi al-Itsarī) yang di antaranya adalah:

\section{Lebih Mengikuti al-Mutāshabihāt dan Mengabaikan al- Muhkamāt}

Menurut al-Qardawī mengikuti ayat-ayat al-Mutāsabihāt dan meninggalkan konteks-konteks yang telah jelas (muhkamāt) merupakan penyimpangan yang paling berbahaya dan paling besar resikonya dalam memahami al-Qur'an secara khusus dan nas-nas secara umum. ${ }^{19}$ Inilah pangkal penyimpangan dan ketergelinciran tentang pemahaman yang benar pada al-Qur'an dan sunnah, yaitu meninggalkan sesuatu yang jelas dan dalildalil terang dan malah lebih memilih mengikuti mutasābihah yang rentan terhadap takwil. Seharusnya meninggalkan sesuatu yang tidak jelas pada yang pasti, atau masalah yang mutashābihah pada yang muhkamāt. ${ }^{20}$

Karena itu, Rasulullah saw mengingatkan umatnya dari mereka yang menyimpang dan bersandar para mutashābihat dan justru meninggalkan hal yang sudah jelas dan muhkam. Dalam riwayat dari 'Á'ishah ra bahwa Rasulullah saw membaca;

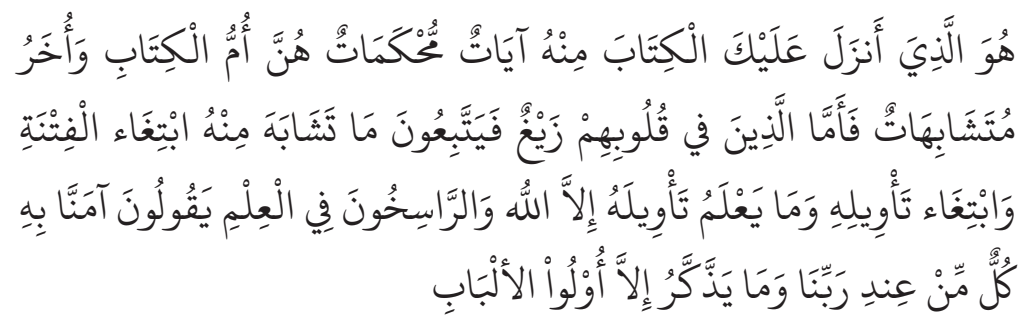

19 Yang dimaksud dengan Muhkam di sini adalah ayat-ayat yang secara jelas secara otomatis dan menunjukkan maknanya secara gambling. Lihat; Yūsūf al-Qardawī, Kayfa Nata'āmal Ma'a alQur'ān, cetakan ketiga (Al-Qāhirah, Dār al-Shurūq, 2000), h. 267.

20 Yūsūf al-Qardawī, Kayfa Nata'āmal Ma'a al-Qurān, cetakan ketiga (Al-Qāhirah, Dār alShurūq, 2000), h. 273. 
"Dia-lah yang menurunkan al-Kitab (al-Qur'an) kepada kamu. Di antara (isi) nya ada ayat-ayat yang muhkamaat itulah pokok-pokok isi al-Qur'an dan yang lain (ayat-ayat) mutasyaabihaat. Adapun orang-orang yang dalam hatinya condong kepada kesesatan, maka mereka mengikuti sebagian ayat-ayat yang mutasyabihat untuk menimbulkan fitnah dan untuk mencari-cari taswilnya, padahal tidak ada yang mengetahui ta wilnya melainkan Allah. Dan orangorang yang mendalam ilmunya berkata: "Kami beriman kepada ayat-ayat yang mutasyabihat, semuanya itu dari sisi Tuhan kami.» Dan tidak dapat mengambil pelajaran (daripadanya) melainkan orang-orang yang berakal.” (QS. Äl 'Imrān [3]: 7).

'Ā'ishah ra berkata, "Rasulullah saw bersabda. 'Jika kalian melihat kelompok yang mengikuti ayat-ayat mutashābihat mereka adalah orang yang dimaksud Allah dengan firman-Nya. Hati-hatilah pada mereka."'21

Mereka berdalih pula bahwa kaum kafir akan masuk surge dengan memutlakkan firman Allah swt, "Sesungguhnya orangorang mu'min, orang-orang Yahudi, orang-orang Nasrani dan orang-orang Shabiin, siapa saja di antara mereka yang benar-benar beriman kepada Allah, hari kemudian dan beramal saleh, mereka akan menerima pahala dari Tuhan mereka, tidak ada kekhawatiran terhadap mereka, dan tidak (pula) mereka bersedih hati (QS. AlBaqarah [2]: 62).

Padahal Allah swt telah menjelaskan makna pada ayat

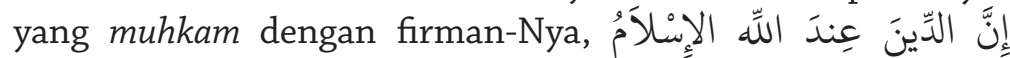
Sesungguhnya agama (yang diridhai) di sisi Allah hanyalah Islam. (QS. Âl'Imran [3]: 19). Juga pada ayat lain, "Barangsiapa mencari agama selain agama Islam, maka sekali-kali tidaklah akan diterima (agama itu) daripadanya, dan dia di akhirat termasuk orang-orang yang rugi.” (QS. Āl ‘Imran [3]: 85).

21 Muslim ibn Hajjāj ak-Qushayrī, Sahīh Muslim, bab Minhu Ayāt al-Muhkamāt, sumber http:// tinyurl.com/mrjnet2 (diakses 21/10/2018)

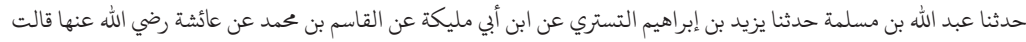

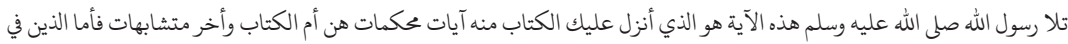

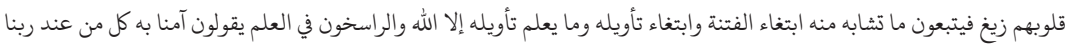

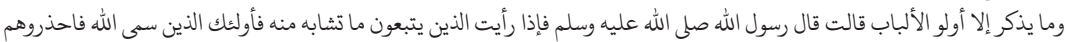




\section{Penakwilan Buruk}

Sudah menjadi kesepakatan para ulama bahwa hukum asal pada tiap kata adalah makna zahirnya yang menunjukkan pada makna aslinya secara lughawi. Akan tetapi, jika diperlukan penakwilan, maka kata tersebut akan berubah dari makna hakikatnya, dans etiap penakwilan pada pada sesuatu pastilah dibutuhkan dalil-dalil atau indicator yang memalingkan dari makna aslinya. Sebagai contoh Allah swt berfirman:

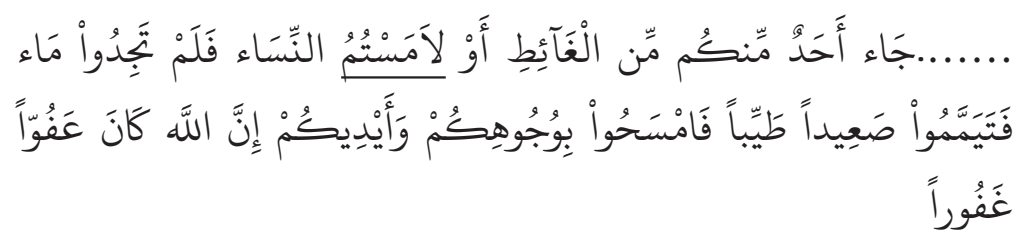

kembali dari tempat buang air atau kamu telah menyentuh perempuan, kemudian kamu tidak mendapat air, maka bertayamumlah kamu dengan tanah yang baik (suci); sapulah mukamu dan tanganmu. Sesungguhnya Allah Maha Pema`af lagi Maha Pengampun. (QS. Al-Nisā [4]: 43).

Ungkapan 'lāmastum' pada ayat di atas maknanya adalah melakukan hubungan seksual dan bukan bersentuhan sebagaimana hal ini dikokohkan oleh Ibn 'Abbās dengan ucapannya, "Sesungguhnya, sentuhan, bersentuhan dan mendatangi (wanita) itu bermakna hubungan seksual, namun Allah mengkiaskannya dengan ungkapan yang dikehendakiNya. ${ }^{22}$ Dengan demikian, penakwilan bisa diterima bila ada dalil yang jelas baik dari sisi bahasa, syara atau akal. Kalau tidak demikian, maka dengan sendirinya tertolak siapapun yang mengatakannya. ${ }^{23}$

Dalam ayat-ayat hukum pidana kasus perzinahan misalnya Allah swt berfirman, "Perempuan yang berzina dan laki-laki yang berzina, maka deralah tiap-tiap seorang dari keduanya seratus kali

22 Muhammad Ibn Jarir al-Tabarī, Tafsīr al-Tabarī, surat al-Nisā’ ta'wil firman-Nya, aw lamastum. Sumber; http://tinyurl.com/08cnnye. (diakses 22/9/2018).

23 Yūsūf al-Qardawī, Kayfa Nata'āmal Ma'a al-Qurān, cetakan ketiga (Al-Qāhirah, Dār alShurūq, 2000), h. 284-285. 
dera...." (QS. Al-Nūr [24]: 2). Pada ayat kasus pencurian, "Lakilaki yang mencuri dan perempuan yang mencuri, potonglah tangan keduanya..." (QS. Al-Mā'idah [5]: 38). Mereka berargumen bahwa perintah dijatuhkannya hukum seperti dera dan potong tangan adalah sesuatu yang mubah dan bukanlah hal yang wajib. Begitu pula pada potong tangan bagi pencuri, hal demikian itu bukan berarti hukuman itu wajib dan tidak bisa dialihkan pada hukuman lainnya pada seluruh kasus pencurian, namun yang dimaksud adalah hukuman terberat bagi pencurian adalah pemotongan tangan.

Ijtihad semacam ini adalah pada kasus penakwilan yang buruk akan tertolak pada pencetusnya sendiri. Karena dia telah melakukan di medan yang tidak ada tempat untuk ijtihad, berijtihad pada hal yang sudah kokoh dan pasti datangnya ketentuan itu dari al-Qur'an dan al-Sunnah serta kesepakatan umat. Sebagaimana dapat disaksikan bahwa perintah dalam ayat ini li al-wūjūb (wajib) dan tidak ada terdapat indikator yang mengalihkan dari perintah aslinya. ${ }^{24}$

\section{Meletakkan Kalimat (nās) Bukan di Posisinya}

Termasuk sebab penyimpangan dalam penafsiran alQur'an dan patut diperhatikan adalah 'meletakkan ucapan atau ketetapan bukan pada tempatnya.' Banyak sekali ketetapan yang benar dan tidak terdapat kecacatan sama sekali sebagaimana pada ayat-ayat al-Qur'an atau sabda-sabda Nabi saw yang sahih, namun mereka gunakan hal tersebut sebagai argumen pada satu kasus atau masalah yang tidak ada hubungannya sama sekali dengan ketetapan itu. Penyimpangan itu akibat pemahaman yang buruk pada ketetapan itu.

Ketika kaum Khawarīj menolak arbitrasi saat perang alSiffin, mereka berpegang teguh pada al-Qur'an, "....... إن الحم... لل لله mereka memang sesuatu yang harus diterima karena hal itu telah ditetapkan Allah swt secara gambling dalam al-Qur'an

24 Yūsūf al-Qardawī, Kayfa Nata'āmal Ma'a al-Qur'ān, cetakan ketiga (Al-Qāhirah, Dār alShurūq, 2000), h. 313. 
sebagimana yang terdapat dalam surat al-'An'ām 114 dan lainnya. Namun hal itu dibantah oleh Ali kw dengan ucapannya, "Ungkapan yang benar namun tujuannya batil." Dalam alQur'an banyak dirilis masalah arbitrasi sebagaiman pada ayat, "Dan jika kamu khawatirkan ada persengketaan antara keduanya, maka kirimlah seorang hakam dari keluarga laki-laki dan seorang hakam dari keluarga perempuan....." (QS. Al-Nisā’ [4]: 35).

\section{Klaim Nasakh Tanpa Dalil}

Ketergelinciran dalam penafsiran selanjutnya adalah adalah pernyataan yang menyatakan bahwa di dalam al-Qur'an ada ayat yang dihapus (mansūkh) tanpa ada dalil yang pasti.

Namun, ada ayat-ayat yang membuat 'gelisah' para ahli tafsir dalam memahami ayat-ayat yang diberi nama 'Ayāt alSayf yang telah menghapus ayat-ayat yang memerintahkan agar bersabar, berdamai, lemah lembut dan ajakan pada hikmah serta nasehat dan dialog dengan cara yang baik dalam firmanNya, "Serulah (manusia) kepada jalan Tuhanmu dengan hikmah dan pelajaran yang baik dan bantahlah mereka dengan cara yang baik....." (QS. Al-Nahl [16]: 125), juga firrman-Nya. "Bersabarlah (hai Muhammad) dan tiadalah kesabaranmu itu melainkan dengan pertolongan Allah dan janganlah kamu bersedih hati terhadap (kekafiran) mereka dan janganlah kamu bersempit dada terhadap apa yang mereka tipu dayakan." (QS. Al-Nahl [16]: 127), serta pada ayat, "Dan bersabarlah terhadap apa yang mereka ucapkan dan jauhilah mereka dengan cara yang baik." (Q.S. Al-Muzammil [73]: 10). Mereka telah mengklaim bahwa ayat-ayat di atas tersebut telah dihapus dengan ayat al-Sayf tadi.

Ayat yang berbunyi, "Apabila sudah habis bulan-bulan Haram itu, maka bunuhlah orang-orang musyrikin itu di mana saja kamu jumpai mereka, dan tangkaplah mereka. Kepunglah mereka dan intailah di tempat pengintaian." (QS. TAwbah [9]: 5) adalah ayat yang berbicara tentang kaum Musyrikin Arab yang mulai menyerang Nabi saw dan melakukan maker serta melanggar perjanjian. dari situ, Allah memmerintahkan hal tersebut, 
atau dengan kata lain bahwa ayat tersebut disesuaikan dengan kondisi saat itu. ${ }^{25}$

\section{Ketidaktahuan Terhadap Sunnah dan Āthar}

Termasuk dalam faktor ketergelinciran dan penyimpangan penafsiran al-Qur'an adalah tidak mengerti tentang al-Sunnah serta Āthar atau sengaja berpaling dari keduanya. Padahal di dalam al-Qur'an dijelaskan pada Sunnah adalah penjelas alQur'an dalam firman-Nya, “......Dan Kami turunkan kepadamu Al Qur'an, agar kamu menerangkan kepada umat manusia apa yang telah diturunkan kepada mereka..." (QS. Al-Nahl [16]: 44).

Pada ayat, "Laki-laki yang mencuri dan perempuan yang mencuri, potonglah tangan keduanya (sebagai) pembalasan bagi apa yang mereka kerjakan dan sebagai siksaan dari Allah....." (QS. Al-Mā'idah [5]: 38). Mereka mengkalim bahwa pencurian saat itu adalah pencurian pada sesuatu yang sangat berharga yang dimiliki oleh orang Arab yaitu unta. Unta merupakan poros kehidupan mereka, nilai keberadaan dan keberlangsungan mereka. Karena itu, bila ada seseorang yang mencurinya maka itu seolah-olah sama saja dengan membunuhnya. Namun, saat ini keadannya sudah berubah, maka seyogyanya hukuman itu pun harus berubah pula. ${ }^{26}$

Jika kembali kembali kepada hadis-hadis sahih mereka akan mendapatkan bahwa klaim mereka itu sama sekali tidak berdasar, karena tidak ada satu kejadian pun pada masa Nabi tentang pencurian unta. Justru unta adalah ternak yang berhamburan di jalan-jalan dan tidak diganggu sama sekali. ${ }^{27}$ Sebagai contoh saat Nabi saw ditanya tentang kambing yang tidak ada pemiliknya, Nabi memerintahkan agar segera ditangkap demi keselamatannya seraya berkata, "Ambillah karena sesungguhnya ia adalah milikmu atau milik saudaramu

25 Yūsūf al-Qardawī, Kayfa Nata'āmal Ma'a al-Qur'ān, cetakan ketiga (Al-Qāhirah, Dār alShurūq, 2000), h. 328.

26 Yūsūf al-Qardawī, Kayfa Nata'āmal Ma'a al-Qur'ān, cetakan ketiga (Al-Qāhirah, Dār alShurūq, 2000), h. 334.

27 Ini adalah bantahan al-Qardāwī di dalam bukunya Kayfa Nata'āmal Ma'a al-Qur'ān, cetakan ketiga (Al-Qāhirah, Dār al-Shurūq, 2000), h. 334. 
atau serigala." 28

Dalam riwayat al-Tabari riwayat dari Abī Umāmah al-Bāhilī secara marfū' tertulis ketika memaknai kata غَيَّا dia berkata, “......Apakah yang dimaksud dengan غَيَّا? Dia berkata, “Itu adalah sumur di dasar api neraka..." Padahal di dalam al-Qur'an Allah swt berfirman:

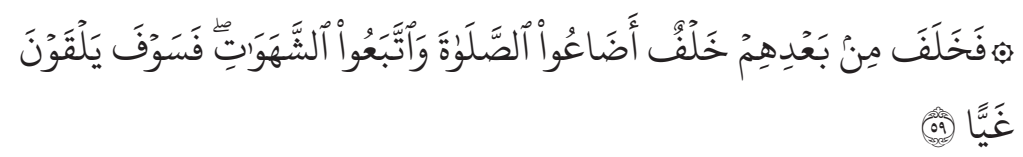

Maka datanglah sesudah mereka, pengganti (yang jelek) yang menyia-nyiakan shalat dan memperturutkan hawa nafsunya, maka mereka kelak akan menemui kesesatan. (QS. Maryam [19]: 59).

غوى - غَيَّا يغوي pada ayat tadi adalah masdar dari kata yang maknanya berlawanan dengan kata petunjuk. Dengan demikian, Ibn 'Abbās memaknainya, 'kerugian' sedangkan Qatādah memaknai 'jahat' dan Ibn Zayd memberi makna 'kesesatan'. Sebagaimana hal ini dinukil oleh Muhammad Amin al-Sanqīiti dalam tafsirnya. ${ }^{29}$ Sebagai contoh pada ayat lain yang berbicara mengenai غيَّ, Allah swt berfirman:

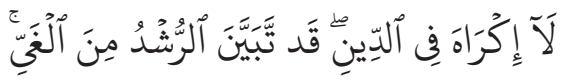

"Tidak ada paksaan untuk (memasuki) agama (Islam); sesungguhnya telah jelas jalan yang benar daripada jalan yang sesat." (QS. Al-Baqarah [2]: 256). ${ }^{30}$

\section{Lebih Percaya Kepada Isrā'iliyāt}

Isrā'iliyāt termasuk salah faktor penyebab penyimpangan dan ketergelinciran penafsiran al-Qur'an. Penyimpangan ini berupa tindakan mempercayai tipe penafsiran dari sumbersumber Isrā'iliyāt yang telah banyak memenuhi kitab-kitab

28 Hadis riwayat Imam Muslim dari Zayd ibn Khālid al-Jahnī. Sumber http://shamela.ws/ browse.php/book-9289/page-240. (22/9/2018).

29 Muhammad Amin al-Sanqītī, Kitāb Adwā' al-Bayān, juz 4, hal. 6. Sumber; http://tinyurl. com/pgkf6da. (22/9/2018).

30 Yūsūf al-Qardawī, Kayfa Nata'āmal Ma'a al-Qurān, cetakan ketiga (Al-Qāhirah, Dār alShurūq, 2000), h. 337. 
tafsir terkemuka terutama pada masalah cerita para nabi dan orang-orang mukmin dalam al-Qur'an, yang di dalamnya terdapat berbagai khurafat dan berbagai kebohongan yang justru mencoreng nama Islam serta pemeluknya. Isrā'iliyāt merupakan senjata lain kaum Yahudi, setelah kekalahan militer mereka, untuk menyerang Islam dari dalam.

Dalam sejarah dijelaskan bahwa Isrāiliyāt sudah mulai menyusup ke dalam Islam semenjak awal Islam. hal ini seperti dijelaskan dalam hadis yang dikutip al-Haythami dalam Majma' al-Jawāidhnya dan menurut Syaikh Ahmad 'Abd al-Rahman al-Bana menyatakan baik (hasan) lantaran banyak mata rantai transmisinya bahwa Rasulullah saw melihat lembaranlembaran kitab Taurat di tangan 'Umar (ibn Khattāb) maka Rasulullah saw marah dan berkata, "Apakah engkau bimbang pada agamamu wahai putra al-Khattab? Aku telah membawa ajaran agama yang putih bersih, demi yang jiwaku berada di tangan-Nya kalau sekiranya (nabi) Mūsā hidup pastilah dia akan mengikutiku."31

\section{Lari dari Kesepakan Umat}

Tidak mengindahkan apa-apa yang datang dari para pendahulu (salaf) dan lari dari peninggalan mereka lalu memulai segala sesuatu dari titik nol atau kosong sama sekali tanpa ada fondasi dan cabang sebelumnya dianggap termasuk ke dalam penyimpangan dalam penafsiran al-Qur'an.

Salah satu pegangan yang paling kokoh serta aturan penting memahami ajaran Islam serta ketetapan-ketetapan al-Qur'an dan Sunnah Nabinya adalah berpegang pada hal-hal yang sudah disepakati oleh umat, aqidah dan pola pikirnya berdasarkan padanya, ketentuan dan taklidnya tertanam padanya dan dari sanalah akan bercabang aturan serta sepak terjangnya. ${ }^{32}$

31 Nur al-Dīn 'Ali ibn Abī Bakar al-Haythamī, Majma' al-Zawā’id wa Manba' al-Zawā’id. Sumber; http://islamport.com/d/1/mtn/1/81/2959.html. (22/9/2018). Seperti juga dikutip oleh Yūsūf alQardawī, Kayfa Nata'āmal Ma'a al-Qur'ān, cetakan ketiga (Al-Qāhirah, Dār al-Shurūq, 2000), h. 346.

32 Yūsūf al-Qardawī, Kayfa Nata'āmal Ma'a al-Qur'ān, cetakan ketiga (Al-Qāhirah, Dār alShurūq, 2000), h. 350 . 
Keharusan mengacu kepada para ahli dan para pakar yang mumpuni dalam bidangnya dinyatakan dalam ayat, “.....maka bertanyalah kepada orang yang mempunyai pengetahuan jika kamu tidak mengetahui...." (QS. Al-Nahl [16]: 43) atau ayat, “.....maka tanyakanlah kepada yang lebih mengetahui.....(QS. AlFurqan [25]: 59). Padahal Allah swt telah menjelaskan pada firman-Nya, “......Kemudian jika kamu berlainan pendapat tentang sesuatu, maka kembalikanlah ia kepada Allah (Al Qur'an) dan Rasul (sunnahnya), jika kamu benar-benar beriman kepada Allah dan hari kemudian....." (QS. Al-Nisā’ [4]: 59). Jika tidak, maka akan datang di kemudian hari setiap orang akan mempunyai penafsiran sendiri kepada al-Qur'an. ${ }^{33}$

\section{Lemah dalam Ilmu Pengetahuan}

Termasuk faktor-faktor penyimpangan dalam penafsiran alQur'an adalah kelemahan seseorang dalam ilmu penegtahuan. Padahal para ulama sejak dahulu kala telah meletakkan syaratsyarat bagi siapa saja yang hendak menafsirkan al-Qur'an agar memperdalam ilmu pengetahuan serta norma-norma di samping keilmuannya dalam agama. Diantara syarat-syarat itu adalah penguasan Bahasa Arab, faham tentang makna hakiki dan kiasan, bisa membedakan mana ungkapan gamblang atau mengandung makna lain, faham ilmu Nahwu, Saraf dan Sastra agar tidak tergelincir dalam penafsirannya.

Misalnya kekeliruan teori yang menyatakan bahwa bahwa wanita (Hawwā) adalah ciptaan Allah yang pertama sebelum nabi Adam dengan dalih ayat al-Qur'an:

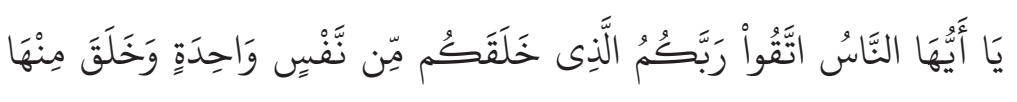

زَوْجَهَا

"Hai sekalian manusia, bertakwalah kepada Tuhan-mu yang telah menciptakan kamu dari diri yang satu, dan daripadanya Allah menciptakan isterinya....." (QS. Al-Nisā [4]: 1).

33 Yūsūf al-Qardawī, Kayfa Nata'āmal Ma'a al-Qur'ān, cetakan ketiga (Al-Qāhirah, Dār alShurūq, 2000), h. 350 . 
Alasannya adalah kalimat Zawjahā adalah suaminya yaitu Nabi Adam. Dengan demikian, kalau sekiranya Adam adalah makhluk pertama dan kemudian wanita yang diciptakan darinya, niscaya ayat tersebut akan berkata وَخَلَقَ مِنْهَا زَوْجَتَتَهَ dan hal ini adalah bahasa yang dikenal di kalangan masyarakat.

Padahal jika membuka ayat lain dengan cerita yang sama dalam al-Qur'an,

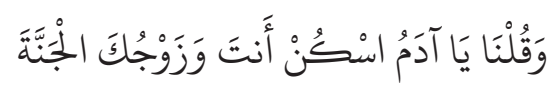

"Dan Kami berfirman, 'Hai Adam diamilah oleh kamu dan istrimu

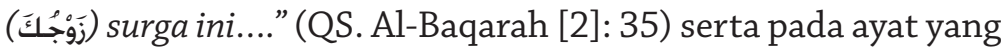
lain terkait dengan masalah Hārūt dan Mārūt,

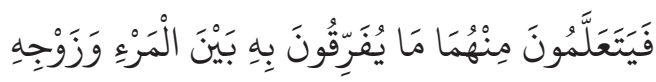

"Maka mereka mempelajari dari kedua malaikat itu apa yang dengan sihir itu, mereka dapat menceraikan antara seorang (suami) dengan isterinya....." (QS. Al-Baqarah [2]: 102). Maka terlihatlah kekeliruan teori di atas yang muncul karena kejahilan dia akan al-Qur'an dan Bahasa Arab.

\section{Fanatisme Mazhab}

Munculnya berbagai madzhab keagamaan, sangat mempengaruhi tafsir al Qur'an. Hal itu terjadi karena al Qur'an merupakan acuan pertama bagi kaum muslimin pendukung madzhab-madzhab tersebut. mereka berusaha mencari dalil untuk mendukung madzahabnya masing-masing, meskipun dengan cara mencocokkan teks atau nash al Qur'an dengan pandangan madzhabnya itu. Mereka menafsirkannya sesuai dengan jalan pikiran dan keinginannya, serta mena'wilkan ayat yang berbeda dengan pendapat madzhabnya sehingga tidak tampak berlawanan dan bertentangan dengan madzhab serta kepercayaannya.

Setiap golongan berusaha mendukung mazhabnya dengan segala cara, sekalipun dengan cara menundukkan ayat-ayat alQur'an sebagai upaya pembenaran terhadap ajaran mazhabnya. 
Penyimpangan disebabkan fanatisme sekte akidah dan madzhab fiqih, misal:

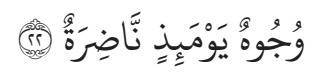

Wajah-wajah (orang-orang mu>min) pada hari itu berseri-seri (QS. Al-Qiyamah [75]: 22).

Mu'tazilah berpendapat bahwa ayat yang muhkam adalah firman-Nya:

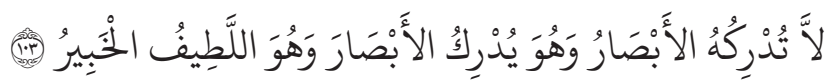

Dia tidak dapat dicapai oleh penglihatan mata, sedang Dia dapat melihat segala penglihatan itu dan Dialah Yang Maha Halus lagi Maha Mengetahui (QS. Al-An'am [6]: 103).

Sedang ayat yang mutasyabih yaitu firman-Nya:

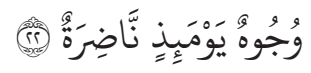

Maka sebagaimana bunyi kaidah bahwa ulama yarudduuna almutasyabih ila al-muhkam fayashiru kulluhu muhkam (mengembalikan yang mutasyabih kepada yang muhkam sehingga semuanya menjadi muhkam). ${ }^{34}$ Maka Mu'tazilah mengembalikan ayat yang mutasyabih QS. al-Qiyamah [75]: 22- 23 kepada QS. al-An'am [6]: 103.

\section{KESIMPULAN}

Penyimpangan penafsiran terjadi pasca wafatnya Rasulullah saw atau tepatnya di era sahabat serta sesudahnya. Salah satu sebabnya adalah terlambatnya penulisan dan kodivikasi hadis Nabawi hingga satu abad lebih, diabaikannya penulisan sanad pada riwayat penafsiran, adanya kesenjangan politik di masa sahabat serta maraknya fanatisme kelompok membuat penafsiran sangat rentan disisipi oleh siapa saja yang memiliki kepentingan, baik mereka yang berada di luar Islam ataupun di dalamnya.

34 Abdurrahman bin Nashir al-Sa'di, Qawaid al-Hissan, maktabah syamilah, h. 50 
Banyak hal yang menjadi faktor penyebab penyimpangan dalam penafsiran al-Qur'an selain faktor-faktor di atas. Di antaranya sebagaimana yang disusun oleh al-Qardāwi dalam kitabnya yaitu: mengikuti al-Mutāshābihat dan mengabaikan al-Muhkamāt, penakwilan yang buruk, meletakkan kalimat (nas) bukan tidak pada posisi seharusnya, klaim Nasakh tanda dalil, ketidaktahuan terhadap Sunnah dan Āthār, lebih percaya pada Isrāiliyyāt, keberpalingan dari kesepakatan umat dan lemah dalam ilmu pengetahuan. Inilah di antara faktor-faktor yang menyebabkan adanya penyimpangan dalam penafsiran al-Qur'an.

Hendaknya dalam menafsirkan al-Qur'an tidak terpaku hanya pada satu metode saja. Karena ternyata masing-masing metode memiliki kelemahan internalnya sendiri. Kita harus menghindarkan diri dari sikap ekslusif dari hanya bersandar kepada satu metode saja dan bersikap fanatik terhadap kelompok atau golongan tertentu sehingga menimbulkan anggapan bahwa tafsir yang benar hanya tafsir dirinya saja, dan menyalahkan penafsiran al-Qur'an dari mazhab lain. Padahal produk penafsiran al-Qur'an tidaklah absolut karena di dalamnya melibatkan unsurunsur penalaran, kajian dan ijtihad para mufassir yang didasarkan atas kapasitas subjektif yang dimiliki sehingga suatu waktu bisa berubah. Sisi positif dari keragaman metode tafsir adalah adalah bahwa kita disuguhi berbagai pilihan tafsir yang akan menguak berbagai dimensi al-Qur'an yang pada akhirnya akan memperkaya diri kita.[] 


\section{DAFTAR PUSTAKA}

Al-'Asqalānī, Aḥmad ibn Hajar, Fatḥ al-Bārī Bi Sharaḥ Şaḥīh alBukhārī, juz 7 (Al-Qāhirah: Dār al-Hadìth, 2004)

Al-Dhahabī, Muḥammad Ḥusayn, Ittijāhāt al-Munḥarifah fì Tafsìr al-Qur'ān al-Karīm wa Dawāfi'uha wa Daf'uha, cetakan ketiga (al-Qāhirah: Maktabah Wahbah, 1986), 18. Sumber: https://ia801305.us.archive.org/25/items/ emtqkddemtqkdd/emtqkdd.pdf (9/9/18).

al-Dzahabi, Muhammad Husain, al-Tafsìr wa al-Mufassirūn, (Dār alHadīs, Kairo, 2005).

al-Haydari, Kamāl,> al-'Işmah, Baḥth Taḥlīlī Fī D \{au’i al-Manhaj alQư'ānī, cetakan pertama (Bayrūt: Dār al-Kutub al-'Arabī, 2002)

Al-Haythamī, Nur al-Dīn 'Ali ibn Abī Bakar, Majma' al-Zawā'id wa Manba' al-Zawāid. Sumber; http://islamport.com/d/1/ $\mathrm{mtn} / 1 / 81 / 2959 . \mathrm{html}$

Al-Husayn, 'Abd al-Qādir Muhammad, Tamyīz al-Dakhīl fì Tafsīr alQur'ān al-Karīm, Fakultas al-Sharīah wa al-Qānūn, Jurnal Universitas Damascus, edisi 29 tahun 2013 (PDF).

Al-Husayn, 'Abd al-Qādir Muhammad, Tamyīz al-Dakhīl fì Tafsīr alQur'ān al-Karìm, Fakultas al-Sharī’ah wa al-Qānūn, Jurnal Universitas Damascus, edisi 29 tahun 2013 (PDF)

Al-Jurr, Khalìl, Al-Mu'jam al-'Arabì al-Hadìth Larousse (Paris: Maktabah La Rose, 1973)

al-Khatīb, Muhammad 'Ajjāj, Ushūl al-Hadìth, Ulūmuh wa Mustalāhuh, cetakan dan terbitan baru (Bayrut: Dār alFikr li al-Tabāảh wa al-Nashr wa al-Tawzī', 2006)

Al-Munawwar, Said Agil Husin, Al-Qur'an Membangun Tradisi Kesalehan Hakiki, (Tangerang Selatan: Ciputat, 2005) 
Al-Qardawī, Yūsūf, Kayfa Nata'āmal Ma'a al-Qur'ān, cetakan ketiga (Al-Qāhirah, Dār al-Shurūq, 2000)

Al-Qushayrī, Muslim ibn Hajjāj <, Sahīh Muslim, bab Minhu Ayāt alMuhkamāt, sumber http://tinyurl.com/mrjnet2 (diakses 21/10/2018)

Al-Sanqīî̄, Muhammad Amin >, Kitāb Adwā' al-Bayān, Sumber; http://tinyurl.com/pgkf6da

Al-Sibt, Khalid ibn 'Uthmān, Qawāì al-Tafsīr Jam'an wa Dirāsatan, juz 1 (Tanpa Negara, Dār al-'Affān, Tanpa tahun)

al-ȚabāțabāiI, Muḥammad Ḥusayn >, Inilah Islam, Pemahaman Dasar Konsep-konsep Islam, cetakan pertama (Jakarta: Sadra press, 2011)

Al-Tabarī, Muhammad Ibn Jarir, Tafsīr al-Tabarī, Sumber; http:// tinyurl.com/08cnnye

Baljon, J.M.S, Tafsir Qur'an Muslim Modern, pent A. Ni'amullah Mu’iz, (Jakarta: Pustaka Firdaus, 1991)

http://tinyurl.com/qfewtps (22/09/2018).

Rakhmat, Jalaluddin, Tafsir Sufi al-Fatihah, (Bandung: Mizan Media Utama, 2012)

Șāmāli, Muḥammad 'Alī̀, http://wwww.ic-el.com/en/admin/ uploadfolder/articles/48-wilayah\%20part\%20iii.pdf hal $152(20 / 09 / 2018)$.

Șāmāli, Muḥammad 'Alī̀, Understanding God's Mercy Part IV, Quarterly Journal of Islamic Studies, Message of Thaqalayn. Vol 12, No 4 (London: Islamic Centre of England, Winter 1433/2012)

Sālih, Subhī, 'Ulūm al-Hadìth wa Mustalāhuh, cetakan ke tujuh belas. (Bayrut: Dār al-'Ilm Li al-Malāyīn, 1988)

Shihab, M. Quraish, Membumikan al-Qur'an: Fungsi dan Peran Wahyu Dalam Kehidupan Masyarakat, (Bandung: Mizan, 1994) 
Shihab, M. Quraisy, Membumikan al-Qur'an: Fungsi dan Peran Wahyu dalam Kehidupan Masyarakat, (Bandung: Mizan, 2012)

Shihab, Umar, Kontekstualitas Al-Qur'an, kajian tematik atas ayatayat hukum dalam al-Qur'an, (Jakarta: Penamadani, 2003)

Sumber internet:

Mu'jam 'Arabī 'Arabì. http://tinyurl.com/pljctal (24/09/2018).

Mu'jam 'Arabī 'Arabī. http://tinyurl.com/qetz6rh (24/09/2018).

Muslim, http://shamela.ws/browse.php/book-9289/page-240 